\title{
12. STRATIGRAPHY AND SUGGESTED AGES OF BLACK SEA SEDIMENTS CORED DURING LEG 42B'
}

\author{
Peter Stoffers, Heidelberg University, Heidelberg, Germany, \\ Egon T. Degens, Hamburg University, Hamburg, Germany, \\ and \\ Egis S. Trimonis, USSR Academy of Science, Kaliningrad, USSR
}

\begin{abstract}
On the basis of lithology and sedimentary structure, a stratigraphic correlation of the three sites drilled during DSDP Leg $42 \mathrm{~B}$ is attempted. Data reveal an almost continuous section from the upper Miocene to the present. The sediments can be grouped into an upper terrigenous and a lower chemical facies. The chemical facies covers the time interval: upper Miocene-Cromerian. The three major European glacial periods: Elsterian, Saalien, and Weichselian produce a massive terrigenous section up to 450 meters thick. During the Holsteinian, Eemian, and Holocene interglacials, brief marine invasions are indicated by a few meters of nannofossil ooze, sapropel, and micrite intercalations.

The chemical facies formed under shallow water conditions first in a restricted marine, upper Miocene-Pliocene basin, and subsequently in an intermediately deep and fresh water-saline environment. During the Cromerian and extending towards the present, the Black Sea changed into the deep basin of today. Major unconformities recognized at the two western sites ( 380 and 381 ) at the contact of the terrigenous-chemical facies are a result of this tectonic development.
\end{abstract}

\section{BACKGROUND INFORMATION}

Stratigraphic correlations and estimates of geologic age in the Pleistocene in the Black Sea are difficult because the biogenic remains mainly indicate facies and not time intervals. In order to get such estimates, we have to rely on absolute age-dating techniques such as radiocarbon methods. Previous studies on piston cores have shown that three main sediment units were deposited during the past 25,000 years (Degens and Ross, 1974). The most recent (commonly called Unit 1) sediments are principally composed of the coccolith, Emiliania huxleyi. The base of this upper marine unit has an assigned ${ }_{14} \mathrm{C}$ age of about 3000 years. Recent age dating using varve techniques, suggest that this ${ }^{14} \mathrm{C}$ age may be in error by about 2000 years as a consequence of "dead" organic carbon contribution (Degens et al., this volume). The middle unit (Unit 2) is a dark sapropel deposited under brackish conditions. The radiocarbon age at the base of this unit is about 7000 years B.P. which may be too high by 2000 years as suggested by varve dating. Unit 3 , deposited in a fresh water environment, was not completely penetrated by piston cores. The age at the base is about 22,000 years B.P.

\footnotetext{
'The stratigraphic interpretation of the Black Sea cores is still somewhat controversial. The careful reader should refer to other papers and the summary paper in this volume.
}

These facies differences are clearly related to recent environmental changes. They are a result of Pleistocene sea-level fluctuations. In summary, rates of sedimentation are $30 \mathrm{~cm} / 1000$ years for the coccolith unit (10 $\mathrm{cm} / 1000$ years if the initial ${ }^{14} \mathrm{C}$ measurement is correct), $10 \mathrm{~cm} / 1000$ years for the sapropel, and about $1 \mathrm{~m} / 1000$ years for the terrigenous fresh water sediments.

During Leg 42B of the D/V Glomar Challenger, three sites were occupied in the Black Sea (Figure 1). The background information of the sites is summarized in Table 1.

\section{STRATIGRAPHY}

The sediments obtained included terrigenous and various chemical and biogenic varieties. Based on mineralogical and fossil data, we can distinguish 16 distinct lithologic units which correlate among the three sites; these include the three earlier designated units. In Figure 2 a stratigraphic correlation among the three sites is attempted.

The age assignments as well as the Pleistocene nomenclature come from recent chronologies given by Hammen et al. (1971) and Zagwijn (1975).

Units 1 and 2 encountered in previous piston cores were not directly found in the DSDP cores. However, the occurrence of coccoliths and sapropel patches in the first drilled core suggests the presence, although disturbed, of these two top units. Unit 3, a terrigenous mud, is the continuation of the terrigenous facies described from piston cores. 


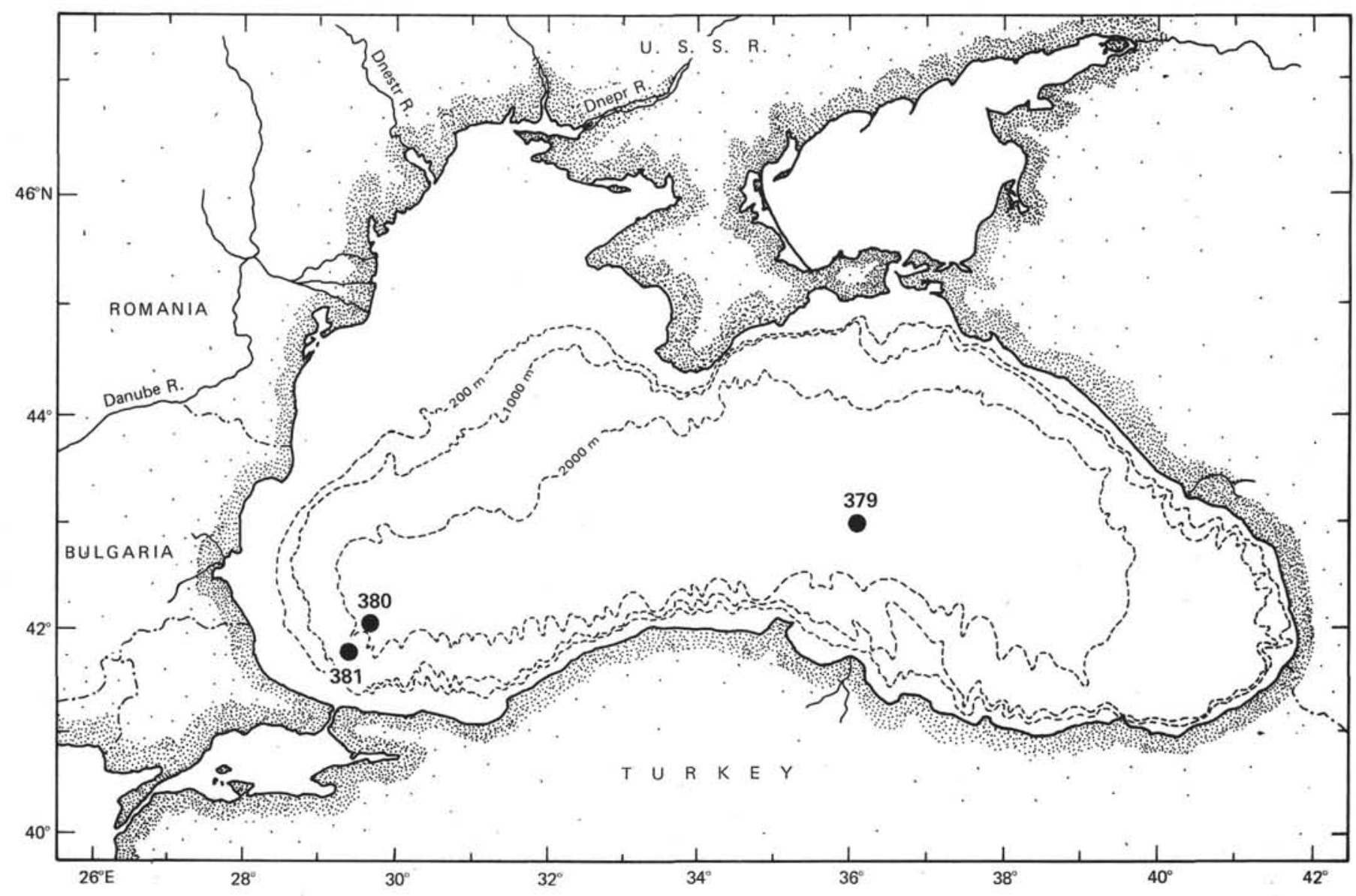

Figure 1. Leg $42 B$ drill sites.

TABLE 1

Leg 42B Coring Summary

\begin{tabular}{|c|c|c|c|c|c|}
\hline Hole & Latitude N & Longitude $\mathrm{E}$ & $\begin{array}{c}\text { Water } \\
\text { Depth (m) }\end{array}$ & $\begin{array}{l}\text { Penetra- } \\
\text { tion }(\mathrm{m})\end{array}$ & Age \\
\hline $379 \mathrm{~A}$ & $43^{\circ} 00.29$ & $36^{\circ} 00.68$ & 2171 & 624.5 & Pleistocene \\
\hline 380 & $42^{\circ} 05.98$ & $29^{\circ} 36.90$ & 2115 & 370.5 & Pleistocene \\
\hline $380 \mathrm{~A}$ & $42^{\circ} 05.94$ & $29^{\circ} 36.82$ & 2115 & 1073.5 & $\begin{array}{l}\text { Pliocene- } \\
\text { late Miocene (?) }\end{array}$ \\
\hline 381 & $41^{\circ} 40.25$ & $29^{\circ} 24.86$ & 1750.5 & 503.5 & Late Miocene \\
\hline
\end{tabular}

For the upper 10 meters of Unit 3, the rate of deposition was in the range of about $1 \mathrm{~m} / 1000$ years. In view of the abundance of turbidites, even higher rates are possible. Since no obvious petrographic and sedimentological changes were noticed in the remainder of this unit, the sedimentation rate could have been maintained at this rate over the length of this unit. Taking an appropriate compaction factor into consideration, the assigned age for the base of this unit is about 60,000 years. Based on the occurrence of fresh water diatoms, Unit 3 was deposited in a fresh water environment when Mediterranean water did not enter the Black Sea. The pollen data indicate a cold climate probably corresponding to the Weichselian (Euxin) glacial stage.

At Site 381 pore water and palynological data suggest that much of the upper terrigenous sequence found at Holes $380 \mathrm{~A}$ and 380 is missing.

Unit 4 consists of a dark greenish gray to medium gray mud characterized by the first appearance of marine diatoms, foraminifers, and nannofossils beneath the Holocene Black Sea deposits. For the nannofossil ooze of Unit 4, a sedimentation rate of 10 to $30 \mathrm{~cm} / 1000$ years was determined. Assuming that the primary production of nannofossil ooze was about the same as in the modern Black Sea, the 1-meter section of pure nannofossil ooze found in this unit (379A, Core 11, 379B, Core 6) was deposited in about 10 to 15,000 years; we assume that the total time for deposition of Unit 4 is 50 to 60,000 years.

Unit 5 is a black sapropel, that has a thickness of 0.3 meters and is intensely compacted. This sapropel was only encountered in Hole 379A, Core 11. Based on the similarity of Units 2 and 5, a sedimentation rate of about $10 \mathrm{~cm} / 1000$ years is assumed for the latter. An age of about 120,000 to 125,000 years is suggested for the base of Unit 5 . The pollen data imply that Units 4 and 5 were deposited during a warm interglacial period, which may relate to the Eemian (Karangat).

Unit 6 is a dark greenish gray terrigenous mud. The diatoms present are all fresh water species with the exception of Core 18 at Site 380 and Core 18 at Hole $379 \mathrm{~A}$ which is characterized as marine (Schrader, this volume). Basically, this unit was deposited in a fresh water environment with one brief marine invasion. The climate was generally cold as indicated by the pollen analyses, with the marine invasion interpreted as a short interstadial period. Unit 6 closely resembles Unit 3 in lithology. It is thus concluded that the deposition rates are about the same for both units, i.e., 1 


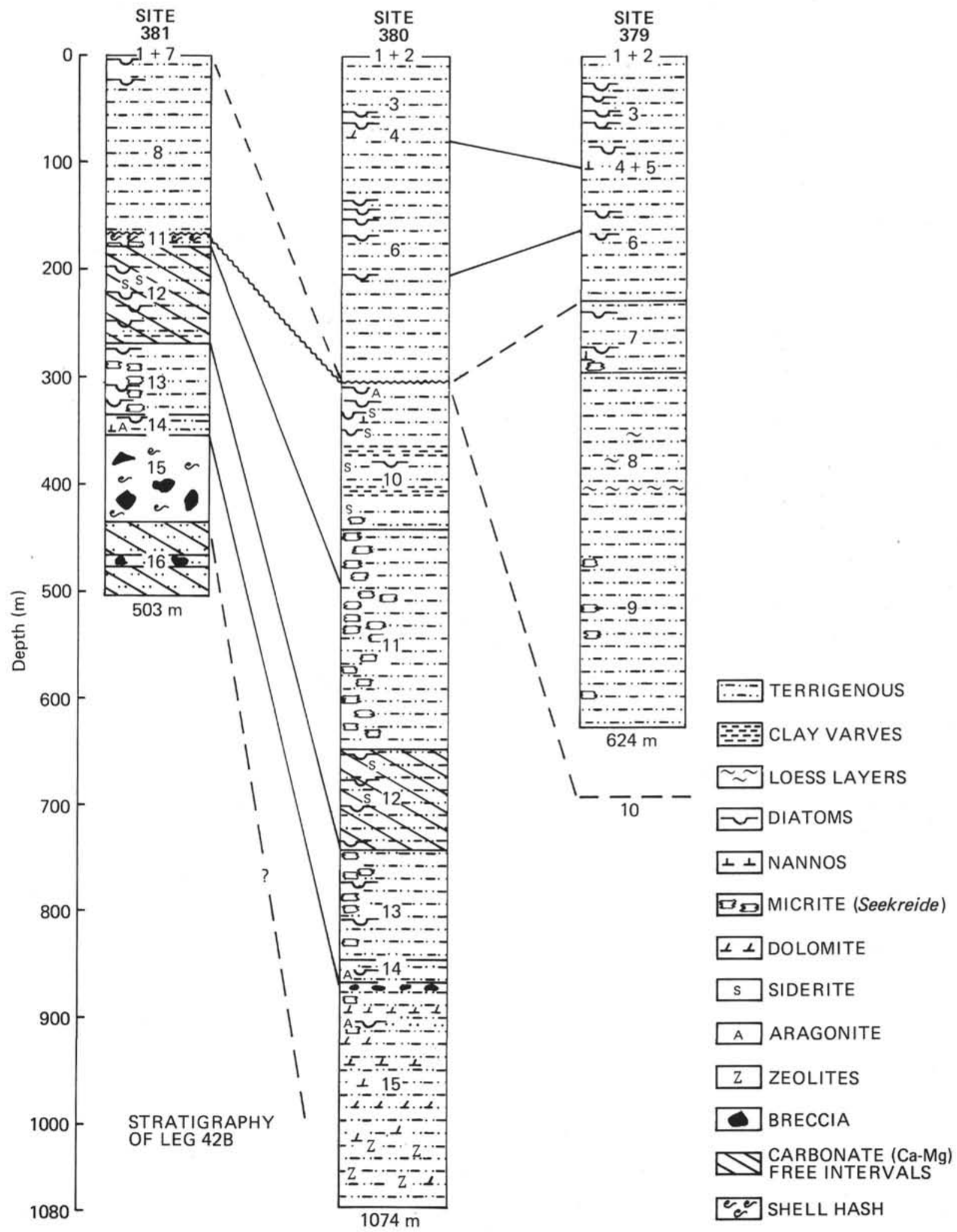

Figure 2. Stratigraphy of Leg $42 B$ sediments. Unit $1=$ nannofossil ooze; Unit $2=$ sapropel; Unit $3=$ terrigenous mud; Unit 4 = nannofossil-rich terrigenous mud; Unit $5=$ sapropel; Unit $6=$ terrigenous mud; Unit $7=$ terrigenous mud with nannofossils; Unit $8=$ terrigenous mud with abundant turbidites; Unit $9=$ terrigenous mud with carbonate cycles; Unit $10=$ sapropelic clay with diatoms, nannofossils, siderite, and varved clays; Unit $11=$ seekreide; Unit $12=$ sapropelic diatomaceous clay with siderite; Unit 13= diatomaceous seekreide; Unit 14 = sapropelic clay with diatoms, nannofossils, and aragonite; Unit 15 = black siltstone with intercalated dolostones (partially breciated) aragonite, calcite, and zeolites; Unit $16=$ black siltstone with an intercalated breccia. 
meter/1000 years and may be even higher at Site 380 . Taking compaction into consideration, the duration for Unit 6 would be around 80,000 to 100,000 years, giving a total age of about 200,000 years at the base of Unit 6 . This unit has been tentatively assigned to the Saalian (Post-Uzunlar) glacial time.

Unit 7 is a diatomaceous nannofossil-rich terrigenous mud. The diatoms and the presence of Braarudosphaera bigelowi indicate deposition in a brackish-marine environment. A correlation with the Holsteinian (Uzunlar) warm period is suggested.

Unit 8 is again a terrigenous mud similar to Units 3 and 6. It is distinguished by the absence of fossil material and the occurrence of abundant turbidites and thin carbonate-rich silty sand layers which may represent loess material. According to the pollen data, the climate was generally cold, possibly corresponding to the Elsterian glacial period (old Euxin-Uzunlar).

Unit 9 is a transition between terrigenous mud and a chemical facies characterized by carbonate varves. The carbonate varves reveal a typical rhythmic pattern consisting of a thin pyrite layer at the base followed by a medium to dark gray mud grading upward into a zone of chondritic burrows (Degens et al., this volume). The top is a light gray marl. Oxygen isotope data (Deuser et al., this volume) and ostracode data (Benson, this volume) suggest a salinar environment similar to Lake Bonneville. The climate was warm. A tentative correlation with the Cromerian (old Euxin) interglacial period is suggested which would give an age of about 700,000 years for the base of Unit 9. This unit was only encountered in Hole 379A and is missing (probably also much of Unit 7 and part of Unit 8) at the two other sites. The base of Unit 8 at Site 381 is characterized by a terrigenous silty sand composed of abundant mollusc fragments and well to subrounded quartz and feldspar grains which may indicate a former marine beach deposit. Below the coarse-grained material a thin Seekreide interval occurs which can be correlated to Unit 11 of Hole $380 \mathrm{~A}$. This implies a major unconformity at Site 381 with a large hiatus of approximately $1,500,000$ years.

At Site 380 the sequence following Unit 6 is distinguished by the presence of diatoms (fresh and marine species), Braarudosphaera bigelowi, together with aragonite, a few thin structureless marly intervals, siderite, and, most striking, varved clays. This sequence is entirely different from the terrigenous section above, and indicates a change in sedimentation regime. A major unconformity corresponding to the one encountered at Site 381 is present except that the hiatus is about 500,000 years.

In Figure 3, we attempt to estimate the corresponding stratigraphic top of Unit 10 in Hole 379A. The pore water data given by Manheim and Schug (this volume) were used to calculate two curves representing the pore water salinity versus core depth. The next step was to find out by differentiation the location where the two curves have equal slopes. The corresponding first derivative $\mathrm{ds} / \mathrm{dD}$ for the curves reveals a difference of about 400 meters in core depth. This is depicted in Figure 3 by the arrows $A$ and $B$ on the left-hand side of the figure and their differentiated functions $\mathrm{A}^{\prime}$ and $\mathrm{B}^{\prime}$

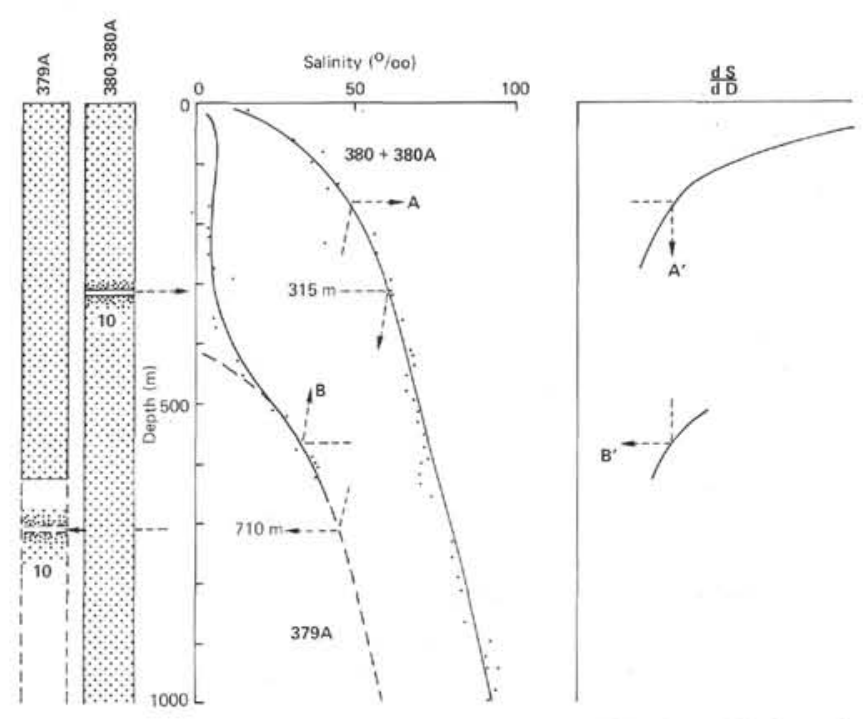

Figure 3. Salinity versus depth curves of Hole $379 \mathrm{~A}$ and Site 380 and their first equation $\frac{\Delta S}{\Delta D}$.

on the right-hand side of the figure. This suggests that the top of Unit 10, which starts at about 315 meters in Holes $380 / 380 \mathrm{~A}$, corresponds to 710 meters core depth in Hole 379A.

The above calculation rests on the assumption that a single saline event has marked the sediment column. In essence, this would be analogous to the so-called "Messinian salinity crisis" of the Mediterranean, except that the Black Sea salinity crisis occurred in the Pleistocene (Post-Chauda-Old Euxin) and represented a hypersaline episode of the type presently developed in the Great Salt Lake rather than a salt deposition. Such a mechanism would give additional support for our assumption of a major unconformity.

Unit 10, a diatomaceous sapropelic clay including siderite, thin marly intercalations, Braarudosphaera bigelowi, and varved clays, is found only at Holes $380 / 380 \mathrm{~A}$. Fossil and pollen data indicate an environment oscillating from cold to warm and fresh to marine, respectively. Obviously, the varved clays were deposited during a cold period. A correlation with the Menap cold and Waal warm period is assumed (PostChauda-Late Chauda).

Unit 11 is characterized by the massive occurrence of Seekreide, part of which may have been deposited by slumping. Isotope data suggest deposition in a fresh water environment and the pollen data indicate a cold climate which may correspond to the Eburon (Early Chauda) cold period. A tentative age of about 1.7 million years is assigned to the base of this unit.

We are aware that at present there is no general consensus on the time of the Plio-Pleistocene boundary, and ranges from 1.5 to 2.6 million years are reported in the literature. Using the Berggren-Van Couvering scale, units older than 1.5 million years would fall into the Pliocene. We have adopted the scale and terminology of Zagwijn (1975) which has been dated by paleomagnetic and other absolute age dating techniques and is based on the European stratigraphy. According to Zagwijn, the Pliocene would start about 1 million years earlier. 
Unit 12 is composed of a diatomaceous sapropelic clay with lithified siderite layers. It was deposited under a warm climate in a fresh water environment as suggested by pollen and diatom data, probably corresponding to the Teglian. An age of about 2.2 million years is assumed for the base of this unit.

Unit 13 consists of laminated Seekreide, laminated diatomites and diatomaceous marls. The diatoms are interpreted as brackish-marine. They change to nearly fresh water species towards the top of this unit indicating a gradual decrease in salinity. Pollen data reveal a generally warm climate which may represent the Preteglian warm period. An intermediate depth is indicated.

Unit 14 is a diatomaceous sapropelic clay with intercalated laminated aragonites. Isotope data, as well as the occurrence of Braarudosphaera bigelowi, diatoms, and Bolivina microfauna signify a brackishmarine environment. The climate was warm as shown by the pollen. This unit marks the Plio-Pleistocene boundary. Its base starts with the marine Akcagyl transgression that transformed wide areas of Russia into a shallow sea by uniting the Black Sea, the Caspian Sea, and Lake Aral. A gradual deepening of the Black Sea during this period is assumed by Degens and Paluska (this volume).

Unit 15 consists of a dark siltstone with intercalated dolostones, aragonite, and zeolites. At Site 381, recovery of this unit was less than $10 \%$ and only brecciated sediments were encountered. A breccia was also found in Hole $380 \mathrm{~A}$ in the uppermost core of this unit. Intraclasts, dolomitized crusts, algal mats, pellets, and oolites indicate a very shallow environment with occasional subaerial exposure and supratidal evaporitic conditions (Stoffers and Müller, this volume). The diatoms present in Hole $380 \mathrm{~A}$ are characteristic of a very shallow marine environment (Schrader, this volume). The differences observed at both sites are interpreted as facies changes caused by their different location $(1750 \mathrm{~m}$ and $2115 \mathrm{~m}$ of water depth, respectively).
Unit 15 of Site 381 was deposited and altered by early diagenetic processes in an intratidal to supratidal environment, whereas at the same time Hole $380 \mathrm{~A}$ was covered by shallow water. The presence of the breccia in Hole $380 \mathrm{~A}$ indicates a shoaling of the sea level with a corresponding subaerial exposure and erosion at Site 381. Whether the lower part of Hole $380 \mathrm{~A}$ consisting of zeolite intercalations also corresponds to this unit is uncertain. The climate was warm as shown by the pollen analyses. The age is Pliocene to late Miocene (Traverse, this volume).

Unit 16 is a dark siltstone with thin siderite layers. Intercalated in the siltstone is a breccia. This unit was encountered at Site 381 only. The diatoms found in Core 48 suggest a fresh water environment (Schrader, this volume). Based on the occurrence of Pine-grass Engelhardia vegetation, this unit is thought to be of late Miocene age, which makes the unit the oldest cored during Leg $42 B$ in the Black Sea.

\section{ACKNOWLEDGMENTS}

We would like to thank D.A. Ross and G. Muller for discussions and comments on the manuscript.

The authors have been supported by the Deutsche Forschungsgemeinschaft. This support is gratefully acknowledged.

\section{REFERENCES}

Berggren and Van Couvering, The Quaternary (preprint).

Degens, E.T. and Ross, D.A., 1974. The Black Sea-geology, chemistry and biology: Am. Assoc. Petrol. Geol. Mem. 20, p. 633.

Hammen, T.V.D., Wijmstra, T.A., and Zagwijn, W.H., 1971. The floral record of the late Cenozoic of Europe. In Turekian, K.K. (Ed.), Late Cenozoic glacial ice ages: New Haven and London (Yale University Press), p. 391-424.

Zagwijn, W.H., 1975. Chronostratigrafie en biostratigrafie: Indeling van het $\mathrm{K}$ wartair op grond van veranderingen in vegetatie an klimaat. In Zagwijn, W.H. and van Staalduinen, C.J. (Eds.), Teolichting bij Geologische Overzihtkaarten van Nederland, Haarlem, p. 109-114. 